\title{
THE IMPLEMENTATION OF TRAUMA HEALING TO THE BULLYING VICTIMS AT RUMAH DUTA REVOLUSI MENTAL SEMARANG
}

\author{
Maryatul Kibtyah ${ }^{1}$, Ana Mawadda Rohmah ${ }^{2}$, Khabib Akbar Maulana ${ }^{3}$ \\ ${ }^{12}$ Walisongo State Islamic University, Semarang, ${ }^{3}$ Gadjah Mada University, Yogyakarta \\ ${ }^{1}$ maryatul.kibtyah@walisongo.ac.id, 2anamawadda24@gmail.com, \\ 3abheeb.maulana@gmail.com
}

\begin{abstract}
This research describes the implementation of trauma healing to the bullying victims at the Rumah Duta Revolusi Mental in Semarang City using Islamic Counseling Guidance. The collecting data technique were interviews, observation, and documentation. Furthermore, the data analysis technique used the Milles and Huberman model, namely: data reduction, data presentation, and data verification. The results showed that the implementation of trauma healing to the bullying victims at the Rumah Duta Revolusi Mental in Semarang City had two forms of programs, namely counseling and psychotherapy including several therapies, namely play therapy, emotional catharsis, fairy tale therapy, and, writing therapy. Meanwhile, trauma healing is carried out through three stages, namely the initial stage, the middle stage or the work stage, and the final stage or the termination stage. Techniques, stage, and strategies show any implementation of goals and functions of Islamic counseling guidance
\end{abstract}

Keywords: trauma healing, bullying, Islamic guidance and counseling.

\begin{abstract}
Abstrak: Penelitian ini menjelaskan tentang implementasi trauma healing pada para korban bully di Rumah Duta Revolusi Mental kota Semarang dengan menggunakan kajian bimbingan konseling Islam. Teknik pengumpulan data disini adalah wawancara, observasi, dan dokumentasi. Adapun Teknik analisis data menggunakan Milles and Huberman Model, Yaitu: reduksi, presentasi, dan verifikasi. Hasil dari penelitian ini menunjukkan bahwa implementasi dari trauma healing pada para korban bully pada Rumah Duta Revolusi Mental di Semarang memiliki dua bentuk program, yaitu: terapi konseling dan psikoterapi yang meliputi beberapa terapi, yaitu: terapi bermain, emosional, dongeng, dan menulis. Sementara itu trauma healing memiliki 3 fase, yaitu fase awal, tengah, dan akhir atau fase pemutusan. Adapun peran, fungsi, strategi dalam proses trauma healing ternyata merupakan implementasi dari fungsi dan tujuan dari bimbingan dan konseling Islam.
\end{abstract}

Kata Kunci: trauma healing, bullying, bimbingan dan konseling islam

\section{A. Introduction}

Currently, bullying is a term that is already familiar to Indonesian people. Bullying is an act of using power to hurt a person or group of people verbally, physically, or psychologically so that the victim feels depressed, traumatized, and helpless. The perpetrator of bullying is often referred to as a bully. A bully knows neither gender nor age. Bullying has often occurred in schools. ${ }^{1}$

The data from the Indonesian Child Protection Commission (KPAI) describes the results of monitoring cases of child abuse in the education sector from January to April 2019. The majority of child rights violations occur in bullying cases. The data shows that violations of children's rights in the field of education are still dominated by bullying, namely in the form of physical violence,

\footnotetext{
${ }^{1}$ Ela Zain Zakiyah, Sahadi Humaedi, and Meilanny Budiarti Santoso. Faktor yang mempengaruhi remaja dalam melakukan bullying. Prosiding Penelitian dan Pengabdian kepada Masyarakat 4 (2). (Bandung: UPI Bandung, 2017).
} 
psychological violence, and sexual violence. Based on complaints received by KPAI, victims of psychological violence and bullying are still the highest. The child victims of policies and physical violence are in second place. While the lowest cases are victims of beatings and sexual violence. There are 8 child victims of the policy, 3 cases of beatings, 3 cases of sexual violence victims. Child victims of psychological violence and bullying have as many as 12 cases and child perpetrators bullying against teachers as many as 4 cases. $^{2}$

The rise of cases of violence that occurs in school-age children today is very concerning for educators, parents, and the community. Schools that were supposed to be placed for children to gain knowledge and build positive personal characters turned out to be places where bullying practices grew. Violence in educational institutions can be committed by anyone, whether it is between friends, between students, between gangs at school, seniors, and even teachers. The location of the incident started from classrooms, toilets, canteens, courtyards, gates, even outside the school. As a result, a school is no longer a fun place for students but instead becomes a scary and traumatizing place. Victims of bullying not only suffer from fear but also in some cases caused death. ${ }^{3}$

Bullying doesn't only happen at school; bullying can happen anywhere. It can even happen through social media interactions or cyberbullyin. ${ }^{4}$ The city of Semarang has a Rumah Duta Revolusi Mental (RDRM) to deal with the phenomenon of bullying which is a follow-up to the Presidential Instruction Number 12 of 2016 concerning Mental Revolution National Movement. RDRM is one of the strategies to strengthen the Semarang City Government in realizing Smart City, Resilient City, Health City, Child-Friendly City, and Great Semarang based on technology. RDRM is a form of program to improve public health services, social welfare, quality education, empowering women in mental health and psychosocial fields using information technology systems and face to face (Interview with a counselor (Mrs. Putri), 8 July 2019). RDRM aims to minimize the incidence of bullying and violence, especially against children and women. The data from Women's Empowerment and Child Protection of Semarang showed that 84 percent of elementary, middle, and high school students in Semarang have been the victims of bullying. Looking at the data, the phenomenon of bullying and violence especially against children and women in Semarang still high. ${ }^{5}$

RDRM activities and strategies to help the trauma of the bullying victim is are the problem of this research. So, this research takes two question to describe the activity of trauma healing based on Islamic counseling guidance. First, about what activities have been carried out by RDRM to treat the trauma experienced by bullying victims. Second, about how the implementation of trauma healing based on Islamic counseling guidance. The goal of this research are to describe the activities of RDRM, so the people beside of Semarang city know and get the understanding of process trauma healing in this place and show how the implementation of trauma healing in this place, also take the Islamic counseling guidance to avoid the trauma.

This study was inspired by several previous studies. On the forms of bullying behavior, the researcher reviewed Kustanti's research which examined the description of bullying cases in the city of Semarang. ${ }^{6}$ This research helps us to explain the types of bullying in Semarang, so that it can be used as an approach to conduct this research. Meanwhile, research on forms of healing for victims of bullying has also been carried out, such as what was done by Hasibuan and Wulandari who used REBT for healing. ${ }^{7}$ Karimah who examined the procedures for healing for victims of

\footnotetext{
${ }^{2} \mathrm{http}: / /$ m.detik.com/, accessed on May 30, 2019

${ }^{3}$ Fransisca Mudjijanti. School Bullying dan Peran Guru dalam Mengatasinya. portal.widyamandala.ac.id, 2012.

${ }^{4}$ Novan Ardy Wiyani. Save Our Children from School Bullying. (Yogyakarta: Ar-Ruzz Media, 2014).

5 http://m.detik.com/, accessed on May 30, 2019.

${ }^{6}$ Erina ratna Kustanti." Gambaran Bullying pada Pelajar di Kota Semarang".Jurnal Psikologi 14, no.1

(2015).pp.29-39. https://doi.org/10.14710/jpu.14.1.29-39

${ }^{7}$ R. L. Hasibuan, \& R. L. H. Wulandari, "Efektivitas Rational Emotive Behavior Therapy (REBT) untuk

Meningkatkan Self Esteem pada Siswa SMP Korban Bullying". Jurnal Psikologi, 11(2).(2015).pp. 103-110.
} 
natural disasters in Banjarnegara, ${ }^{8}$ and Habsyi who explain the problem-solving mindset guidance (PPKM) for victims of bullying in vocational schools with Javanese ethnicity. ${ }^{9}$ All of those researches did not explain about how the Islamic counseling and guidance are also important to help the trauma of the bullying victims. So, this research had a goal to explain the process of trauma healing of bullying victims in another place based on Islamic counseling and guidance.

\section{B. Theoretical Review}

\section{Trauma Healing}

The Psychology Dictionary explains that trauma is any injury, illness, or shock, which is often physical or structural, or mental in the form of emotional shock which results in more or fewer disturbances in the resilience of mental functions. ${ }^{10}$ Cavanagh in Mental Health Channel states about the notion of trauma as an extraordinary event that causes wounds and feelings of pain but is also often interpreted as an injury of severe pain due to an extraordinary event that befalls a person directly or indirectly, either physical injury or psychological injury or a combination of both. The severity of an event will be felt differently by each person so that the influence of the event on behavior is also different from one person to another.11

Meanwhile, healing means healing. Healing also means "to make whole" or a process to restore which has the root words health and whole in English which means to make good or healthy again, make wounds cured, back to the original situation, free from sorrow and difficulties from bad things, make differences lead to reconciliation. ${ }^{12}$

In language, healing means to heal, in the context of trauma healing can be interpreted as an attempt to heal someone from trauma. Trauma healing is closely related to efforts to reconcile, this is about building or improving human relationships related to reducing feelings of loneliness, improving mental conditions, understanding the meaning of peace, reducing feelings of isolation, hatred, and dangers that occur in interpersonal relationships. ${ }^{13}$

Healing indicates that although the human condition will not be the same after being faced with a traumatic experience, it can still restore its balance, its strength is integrated into one unit (whole), so that it functions optimally (functional) and is ready to move through a period of suffering (suffering) and a traumatic negative experience leading to good growth. It is very appropriate that the word healing is used as a word of recovery. ${ }^{14}$

a. Trauma Healing Goal

Trauma healing places more emphasis on the client's recovery from a pre-traumatic state and being able to adapt to the circumstances of the new environment. The purpose of trauma healing for children is to ease depression and can return to normal life as before. ${ }^{15}$

Broadly speaking, the implementation of trauma healing aims to help the recovery of the client's psychological condition, so that they can live a normal life process again and be free

\footnotetext{
${ }^{8}$ Risa Karimah. Trauma Healing Oleh Muhammadiyah Disaster Management Center (MDMC) Untuk Anak Korban Bencana (Studi Kasus Bencana Tanah Longsor di Desa Sampang, Kecamatan Karangkobar, Banjarnegara Jawa Tengah), 2015.

9 Bakhrudin Ali Habsyi. "Model Bimbingan Kelompok Pola Pikir Pemecahan Masalah (PPPM) Untuk Mengembangkan Pikiran Rasional Korban Bullying Siswa SMK Etnis Jawa". Jurnal Pendidikan (Teori dan Praktik) 2 No. 2. (2017).

${ }^{10}$ J. Drever. Kamus Psikologi. Translated by Nancy Simanjuntak, (Jakarta: Bina Aksara, 1998)

${ }^{11}$ Kusmawati Hatta. Trauma dan Pemulihannya. (Banda Aceh: Ar- Raniry Press, 2016).pp.18

${ }^{12}$ John M. Echols \& Hassan Shadiliy. Kamus Inggris - Indonesia. (Jakarta: PT Gramedia Pustaka Utama, 2005).

${ }^{13}$ Jill Gordon. "Fostering students' personal and professional development in medicine: a new framework for PPD". Medical Education Journal 37, no.4 (2003).pp.341-349. https://doi.org/10.1046/j.13652923.2003.01470.x

${ }^{14}$ Kusmawati Hatta. Trauma dan Pemulihannya.pp.113

${ }^{15}$ Nur Iswarso. Mendampingi dan Menyembuhkan Anak-Anak dari Trauma Pelecehan Seksual. (Yogyakarta: Penerbit Indoliterasi, 2017).pp.99
} 
from disturbances due to trauma and directed to targets that have been identified will have an impact on victims. ${ }^{16}$

b. Therapy of Trauma Healing

Some of the therapies commonly used in trauma healing are:

1) Emotional Catharsis is a way to relieve anger by venting anger on other objects that do not harm yourself or others. Examples are: trauma and recovery, popping plastic bags loudly, writing letters. ${ }^{17}$

2) Play Therapy, where the therapist uses play to initiate topics that cannot be initiated directly. This can help children feel more comfortable in the process of their traumatic experiences. ${ }^{18}$

3) Behavioral Therapy, trauma treatment can be through behavioral therapy with trained psychiatrists, psychologists, or other professionals who can help change emotions, thoughts, and behaviors associated with trauma and can help manage panic, anger, and indecision. ${ }^{19}$

4) Cognitive therapy, namely the therapist helps to change irrational beliefs that interfere with emotions and interfere with activities. The goal of cognitive therapy is to identify irrational thoughts, collect evidence that these thoughts are irrational to fight these thoughts, and then adopt more realistic thoughts to help achieve more balanced emotions. ${ }^{20}$

5) Fairy tale therapy, which trains children to learn to empathize, listen, and respect others. The content of fairy tales teaches moral values and how to deal with problems. ${ }^{21}$

6) Writing therapy has cathartic power (emotional release). By writing, a person will be able to calm his mind, release tension, unravel the confusion and open a new path in his life. Writing techniques are appropriate for children aged 10 years too late teens (19 years) and even adults. ${ }^{22}$

\section{c. Trauma Healing Stages}

The stages in the trauma healing process are:23

1) Initial Stage

Consists of introduction, invitation, and environmental support. In this stage, the counselor builds a relationship with the client which is called a working relationship, which is a relationship that is functional, meaningful, and useful so that the client will be able to trust and release all of his heart, feelings, and hopes in connection with the trauma experienced.

2) Middle Stage

Here the counselor focuses on exploring the trauma experienced by the client, through observation and then assessed according to what is explored. This stage is also called stage action. The purpose of this stage is to explore the trauma, and the client's concerns or actions, and the environment in overcoming the trauma.

3) Final Stage or Termination Stage

This stage is marked by several aspects, namely: decreased client's traumatic anxiety, changes in client behavior in a more positive, healthy, and dynamic direction, clear life goals in the future, and changes in positive attitudes towards the trauma faced, as in the

\footnotetext{
16 Kusmawati Hatta. Trauma dan Pemulihannya.pp.141-142

${ }^{17}$ Kusmawati Hatta. Trauma dan Pemulihannya.pp.53

18 Ibid.pp.66

19 Ibid.pp.61-68

20 Ibid.pp.65.

${ }^{21}$ Kuriake Kharismawan. Panduan Program Psikososial Paska Bencana. (Semarang: Center For Trauma Recovery Unika Soegijapranata, 2008).pp.40

22 Ibid.pp.42

23 Kusmawati Hatta. Trauma dan Pemulihannya.pp.132-133
} 
trauma period he was afraid of the sea because he was reminded of the tsunami, but after handling it, he began to come and see the sea.

\section{Bullying}

Olweus in Mawardah says that bullying is a negative action that is raised by someone or more, which is done repeatedly and occurs from time to time. Bullying involves unbalanced power so that the victim is in a state of being unable to defend himself effectively against the negative actions he receives. Almost every child has probably experienced some form of unpleasant treatment from another child who is older or stronger. ${ }^{24}$

According to Law number 23 of 2002 concerning child abuse (UUPA), a child is someone who is not yet 18 years old, including a child who is still in the womb. Bullying can occur in three forms that are physically, verbally, and relationally. Physical bullying can be in the form of hurtful behavior such as hitting, strangling, punching, elbowing, kicking, biting, pinning, spitting, damaging the victim's clothes and belongings. Verbal bullying can take the form of giving nicknames, reproaches, slander, cruel criticism, insults, intimidating emails, sending short messages or anonymous letters containing threats of violence, gossip, abusive calls, and statements that have nuances of sexual solicitation or sexual harassment. While relation bullying can be in the form of a systematic weakening of the victim's self-esteem through neglect, exclusion, or avoidance and intentionally alienate or reject the victim and damage friendships. Relation bullying can also take the form of hidden attitudes such as aggressive glances, sighs, sneers, mocking laughter, eye glances, and rude body language. ${ }^{25}$

The occurrence of bullying is caused by: differences in a class (seniority), economy, religion, gender, ethnicity, or racism, a family that does not get along, school situations that are not harmonious or discriminatory, individual or group character, and wrong perception of value for the victim's behavior. Also, bullying can occur due to differences in social strata, some students feel that they are the strongest, superior, or even higher in social strata than other students, making it easy for them to do bullying to their victims who usually feel less confident and quiet in class. ${ }^{26}$

\section{a. Form of Bullying}

In determining the form of bullying, it can be seen from the contact of the perpetrator with the victim, namely: direct and Indirect. ${ }^{27}$ Meanwhile, Riauskina in Salsabila ${ }^{28}$ classifies bullying behavior into five categories: direct physical contact (hitting, pushing, biting, grabbing, kicking, locking someone in a room, pinching, scratching, also includes extorting and damaging other people's belongings), direct verbal contact (threatening, humiliating, demeaning, harassing, giving name-calling, sarcasm, demeaning, cursing or mocking, intimidating, cursing, spreading gossip), direct non-verbal behavior (looking sarcastically, sticking out tongue, displaying a demeaning, mocking, or threatening facial expression; usually accompanied by physical bullying or verbal), Indirect non-verbal behavior (silencing someone, manipulating friendships into cracks, intentionally ostracizing or ignoring, sending anonymous letters). Sexual harassment (sometimes categorized as physical or verbal aggressive behavior).

b. Role in Bullying

\footnotetext{
${ }^{24}$ Mutia Mawardah. Hubungan antara Regulasi Emosi dengan Perilaku Bullying. (Yogyakarta: Universitas Islam Indonesia, 2009).pp.14

${ }^{25}$ Rosya Linda Hasibuan and Rr. Lita Hadiati Wulandari "Efektivitas Rational Emotive Behavior Therapy (REBT) untuk Meningkatkan Self Esteem pada Siswa SMP Korban Bullying". Jurnal Psikologi 11 Nomor 2, (2015).pp.104

${ }^{26}$ Mutia Mawardah. Hubungan antara Regulasi Emosi dengan Perilaku Bullying.pp.21

${ }^{27}$ Wardha Salsabiela. Hubungan antara Pola Asuh Authoritative Orang Tua dengan Empati Anak pada Bystander Bullying. (Yogyakarta: Universitas Gajahmada, 2010).pp.16-17

28 Ibid.
} 

namely:

Marini, Farbaim, and Zuber (1999) simplified the roles of bullying into three groups,

1) Bullies or the perpetrator is someone who does bullying due to several factors behind it. Based on the research of Mclaughlin, Ray, and Eve (2005), it is stated that the perpetrators of bullying want to hide their feelings of insecurity and boredom towards themselves, and in fact, the perpetrators of bullying can raise self-confidence and self-esteem. ${ }^{29}$

2) Victims are weak individuals, physically and psychologically incapable, socially isolated, always seen alone (looks lonely), insecurity, and have low self-confidence. All children can be victims of bullying. Then, teenagers who are victims of bullying have the characteristics of being easily anxious and having low self-esteem..$^{30}$

3) A bystander is a person who appears to be around and has an intervention role in the occurrence of bullying.

c. The Affector of Bullying

Morrison, et al stated that the occurrence of bullying behavior was caused, among others, by class differences (seniority), economy, religion, gender, ethnicity or racism, families who did not get along, school situations that were not harmonious or discriminatory, individual or group characters, perceptions wrong values for the victim's behavior. ${ }^{31}$

d. Impact of Bullying

Bullying is an aggressive, harmful act and can cause discomfort and trauma to the victim. The impact of bullying causes depression and anger. Victims of bullying also feel sick, stay away from school, decrease academic achievement, increase fear and anxiety, have suicidal ideation, and in the long run will experience internal difficulties that include low selfesteem, anxiety, and depression. The impact of bullying is worse if no one assisting them to solve the problem. The prevention process is an absolute thing that must be done but for victims who have experienced it, a solution is needed so that the problems they face can be resolved and the victims can get out of the problems they face. ${ }^{32}$

\section{Islamic Counseling Guidance}

Adz Dzaky explains counseling from an Islamic point of view, that Islamic counseling means an activity of providing guidance, lessons, and guidelines to individuals who ask for guidance (clients) in terms of how a client should be able to develop the potential of mind, psyche, faith, belief, and can overcome the problems of life and life properly and correctly independently with a view to the Al-Quran and As-Sunnah. ${ }^{33}$

According to Amin, Islamic counseling guidance is a process of providing directed, continuous, and systematic assistance to each individual so that he can develop his potential or religious nature optimally, by internalizing the values contained in the Qur'an and Hadith. ${ }^{34}$ Rasulullah SAW into the client so that he can live in harmony and line with the guidance of the Qur'an and Hadith. Meanwhile, according to Kibtyah Islamic counseling is a process of providing assistance that includes all dimensions of humanity in general counseling, namely the functioning of all elements in a proportional and balanced manner by using the theory and approach of BK in general, but the content is adjusted to the Al-Quran and Hadith that intended for Muslims. ${ }^{35}$

\footnotetext{
${ }^{29}$ Wardha Salsabiela. Hubungan antara Pola Asuh Authoritative Orang Tua dengan Empati Anak pada Bystander Bullying.pp.18

30 Ibid.pp.19

${ }^{31}$ Mutia Mawardah. Hubungan antara Regulasi Emosi dengan Perilaku Bullying.pp. 21

32 Masnurrima Heriansyah. "Strategi Mengatasi Trauma pada Korban Bullying Melalui Konseling Eksistensial". Jurnal Ilmiah dalam Implementasi Kurikulum Bimbingan dan Konseling, (2017).

${ }_{33}$ Hamdani Bakran Adz-Dzaky. Konseling dan Psikoterapi Islam. (Yogyakarta: Fajar Pustaka Baru, 2004).pp.137

${ }^{34}$ Samsul Munir Amin. Bimbingan dan Konseling Islam. (Jakarta: Amzah, 2010).pp.23
}

${ }^{35}$ Maryatul Kibtyah. Sistematisasi Konseling Islam. (Semaarang : RaSAIL Media Group, 2015).pp.106 


\section{a. Purpose of Islamic Counseling Guidance} following: 36

The objectives of Islamic guidance and counseling according to Adz-Dzaky include the

1) To produce a change, improvement, health, and mental and mental cleanliness. The soul becomes calm, docile, and peaceful (muthmainah), is open-minded (radhiyah), gets enlightened and guidance (mardhiyah).

2) To produce a change, improvement, and politeness of behavior that can benefit both oneself, others, and the environment.

3) To produce emotional intelligence in individuals so that a sense of tolerance, solidarity, help, and compassion arises and develops.

4) To produce spiritual intelligence in the individual so that a sense of obedience to Allah arises and develops, carries out all orders and stays away from His prohibitions, and has the steadfastness to accept His tests.

5) To produce divine potential, so that with this potential individual can serve as caliphs properly and correctly, able to overcome various problems in life, provide benefits and safety for the environment.

b. Functions of Islamic Counseling Guidance

The traditional counseling function according to Adz-Dzaky is classified as follows: ${ }^{37}$

1) Remedial of rehabilitative

The remedial role focuses on the problem of (a) Adjusting (b) Healing psychological problems faced (c) Restoring mental health and overcoming emotional disorders.

2) Educative function and development

This function focuses on the problem: help improve skills in life, identify and solve problems in life, help improve the ability to face transitions in life, and help individuals overcome anxiety and improve communication skills.

3) Prevention function

This function helps individuals to be able to actively try to take precautions before experiencing mental problems due to lack of attention. The main function in Islamic counseling which is related to psychology cannot be separated from spiritual issues (beliefs).

\section{Methods}

This research is qualitative research. The data sources were obtained through an interview process in Rumah Duta Revolusi Mental and victims of bullying. While the secondary data in this study were obtained from the parents of victims of bullying, books, journals, modules, archives, or written documents related to data regarding the implementation of trauma healing to children's victims of bullying at the Rumah Duta Revolusi Mental in Semarang. The data collection techniques include Interviews with counselors, administrators, and volunteers of the Rumah Duta Revolusi Mental in Semarang, observation, and documentation. The validity of the data used the triangulation method which is a technique for checking the validity of the data for comparison or checking the data obtained. According to Sugiyono triangulation is divided into three, namely source, technique, and time. ${ }^{38}$

The data analysis technique used the Miles and Huberman model which consists of data reduction, data display, and conclusion drawing/verification with bullying, trauma healing and Islamic counseling and guidance - ${ }^{39}$ we use Adz-dzaky to compare the strategies of trauma healing. ${ }^{40}$ Meanwhile, the result was used the formal and informal method that use some table and explanation within sentence.

\footnotetext{
${ }^{36}$ Hamdani Bakran Adz-Dzaky. Konseling dan Psikoterapi Islam.pp.217

37 Ibid.

38 Sugiyono. Metode Penelitian Pendidikan. (Bandung: Alfabeta, 2016).pp.274

39 Sugiyono. Metode Penelitian Pendidikan. Pp.337

${ }^{40}$ Hamdani Bakran Adz-Dzaky. Konseling dan Psikoterapi Islam.
} 


\section{Results and Discussion}

\section{Implementation of Trauma Healing to Victims of Bullying at Rumah Duta Revolusi Mental in Semarang}

The data from the RDRM of Semarang stated that the accident of bullying happen mostly in September. The case was in the act of pushing, mocking, cursing, isolating, hitting, and threatening as shown in table 1 . The acts of bullying were grouped based on aspects of bullying which included physical, verbal, body cues, and group forms. This is under the statement of Mrs. Putri as the Implementing Coordinator stating that: "Bullying cases in Semarang is still very high. Because people still underestimate the issue of bullying. The problem of bullying is considered a minor problem even though the impact is very large for the victim. Bullying occurs because there are several contributing factors including seniority, religion, economy, gender, ethnicity or racism, individual or group character, wrong perception of value for the victim's behavior".

Semarang service is related to handling victims of bullying, namely trauma healing. The objectives of trauma healing at RDRM Semarang City are:

1. Reducing the intensity of problems involving physical, psychological, psychosocial, and environmental health on individuals, communities, and communities.

2. Increase the positive potential and minimize the negative risk the client has.

3. Accompany and help clients to deal with their problems.

The requirements to join trauma healing program at RDRM are: holding Semarang Identity Card, a statement letter of the client as a referral from an institution, fill out a form and a statement of willingness to take part in the prevention program as a whole, for survivors it is necessary to include letter information on the results of psychological examinations issued by the relevant agencies. The implementers of the trauma healing program are experts in their fields or practitioners including psychologists, psychiatrists, doctors, nurses, therapists, counselors. This is as stated by Mrs. Dinar (Mental Health) who said: "Every victim of bullying is handled by experts in their field with the needs of the client. Experts in their fields include psychologists, psychiatrists, doctors, nurses, therapists, counselors.

The following is a table of data for implementing the trauma healing program at RDRM Semarang:

Tabel 1 Implementation Data of Trauma Healing Program at RDRM Semarang (RDRM Document)

\begin{tabular}{|c|l|l|}
\hline No. & Name & Saving as \\
\hline 1 & Dinar Wukirsari, S.Psi.,M.Psi. & Counselor \\
\hline 2 & Fitri Marshela, S.Psi. & Online Counselor \\
\hline 3 & Siska Eka Pratiwi, S.Psi. & Counselor \\
\hline 4 & Dian Setyo Nugroho, S.H. & Legal Councelor \\
\hline 5 & Nandea Fani Dian Pertiwi & Legal Councelor \\
\hline
\end{tabular}

The competencies of the trauma healing program at RDRM are experts in their fields, not in conflict with the law, not using drugs, not discriminatory, and physically and mentally healthy. The scope of the trauma healing program in RDRM can be applied to the environment, namely family, community, school, and government. The principles of the healing program include several things, namely:

1. The trauma healing program is carried out based on a written agreement and a contract agreement.

2. The trauma healing program as a process cannot be done for a moment and is helpful for clients.

3. As a means of providing information and advice to clients

4. The trauma healing program does not create dependence on the client with the person 
concerned.

5. Trauma healing programs must be neutral in value, respect, and tolerate diversity of culture, religion, race, ethnicity.

6. The process of implementing the trauma healing program is empathetic and therapeutic.

Stages in implementing the trauma healing program are as follows:

1. Build closeness with clients

2. Obtain written consent from the client

3. Collect data and history of clients and their families in full

4. Conduct psycho test (if necessary, adjust the case)

5. Finding problems experienced by clients through observation and interviews

6. Determine the diagnosis and/or a differential diagnosis

7. Determine the goals of the trauma healing program

8. Determine the trauma healing program in the form of counseling and/or psychotherapy

9. Make a contract agreement with the client

10. Conduct the trauma healing program in the form of counseling and/or psychotherapy

11. Provide a written report on the results of the trauma healing program

12. Explain the obstacles experienced and suggestions for further programs and the client's potential for recurrence

The duration of the trauma healing program is a minimum of 1 to 6 months. Funding for the trauma healing program is following the policy of the trauma healing program organizer. The forms of the trauma healing program at Rumah Duta Revolusi Mental at Semarang in the form of: a. Counseling

Counseling at RDRM can be online and offline. In online counseling at RDRM there is a Gerakan Bersama Sekolah Semarang Peduli dan Tanggap (Geber Septi) program. GEBER SEPTI's idea is to increase knowledge, awareness, and community empowerment in the field of psychological intervention in cases of bullying in schools. Also, providing a forum for online psychological and legal consultations for teachers, victims, and perpetrators of bullying and Parents of Students.

This is in line with the statement of Mrs. Fitri who stated that:

"Bullying is a very sensitive thing. It's like Pandora's box, if you don't open it, it's a problem, and if you open it, you'll find more problems. Online counseling is one solution because it can be done by anyone, anywhere, anytime, and clients' identity is secured. Online counseling is also a place to overcome problems when teenagers, teachers, and parents are embarrassed or confused about where to share." 
Tabel 2 Bullying Handling Scheme (RDRM Document)

\begin{tabular}{|c|c|c|}
\hline Family & School & Government \\
\hline $\begin{array}{l}\text { Instilling } \\
\text { character, } \\
\text { responsibility, } \\
\text { tolerance, caring, } \\
\text { mutual respect, } \\
\text { compassion, and } \\
\text { empathy }\end{array}$ & $\begin{array}{l}\text {-Make anti-bullying } \\
\text { rules } \\
\text {-Perform early } \\
\text { identification of } \\
\text { bullying cases } \\
\text {-Perform anti- } \\
\text { bullying activities } \\
\text { together } \\
\text {-Bullying-free at } \\
\text { canteen and toilet } \\
\text { - supervising } \\
\text { program }\end{array}$ & $\begin{array}{l}\text { - Creating a social } \\
\text { organization } \\
\text {-An anti-bullying } \\
\text { curriculum } \\
\text { - Anti-bullying } \\
\text { ambassador } \\
\text { training } \\
\text {-Establishing an } \\
\text { anti-bullying } \\
\text { ambassador in } \\
\text { every school } \\
\text { - Creating a joint } \\
\text { movement on an } \\
\text { anti-bullying day }\end{array}$ \\
\hline
\end{tabular}

The GEBER SEPTI program is a tangible manifestation to improve public mental health services, social welfare, and quality education. Besides, as a form of support for the Child-Friendly School Program, Resilience City, and Smart City. There are two counselors at RDRM, namely legal counselors and psychological counselors. The following are the stages of online counseling:
a. Client
visited website
"GEBER
SEPTI"

www.gebersepti.semarangkota.go.id

b. Clicking the "Consultation" menu

c. Filling in the "Consultation" Form

d. Pressing the "Submit" button

e. The client's problem has been accepted by the counselor

f. Counselors consider various theories as to the basis for alternative problem solving

g. After approximately 3 days the counselor gives a reply via email to the client to provide assistance and response to the client's problem

$\mathrm{h}$. The client determines which problem-solving method is the most appropriate

i. Counselors monitor clients via email

j. Stoping counseling by assessing the results that have been obtained

Besides online consulting, you can also consult offline by coming to the Rumah Duta Revolusi Mental Semarang. Regarding the implementation of offline counseling, Mrs. Putri stated that:

"Offline counseling that was carried out for the first time was extracting client data and we gave them a client's approval letter, if you have agreed to be served, it must be signed by a parent or accompanying person. Only then counseling be carried out."

The stages of offline counseling are as follows:

a. Build closeness with clients

b. Obtain written consent from the client

c. Collect data and history of clients and their families in full

d. Finding problems experienced by clients through observation and interviews

e. Make a contract agreement with the client

f. Conduct counseling

g. The client determines which problem-solving method is the most appropriate

h. Provide a written report on the results of the implementation of counseling

i. Explain the obstacles experienced and suggestions for further programs and the client's 
potential for recurrence.

\section{b. Psychotherapy}

Psychotherapy is a series of methods to help a person overcome mental or psychological problems. Psychotherapy is given by RDRM to victims of bullying for trauma healing using several therapies. This is under the statement of Mrs. Putri which stated that:

"Trauma healing therapy is carried out after the consent of the child's parents by signing the consent letter that has been given. After that, do a psychological assessment of victims of bullying. We see the psychological condition then we do a psychological intervention. The therapy includes play therapy, emotional catharsis, fairy tale therapy, and writing therapy. Various psychotherapy is provided to adjusts the client's condition. Therapy can be done individually or in groups".

Trauma healing programs are given to victims of bullying according to the needs and conditions of the victims. So, each victim received a different trauma healing program. Counseling and psychotherapy can be done individually or in groups, either directly or indirectly.

After conducting the trauma healing program for victims of bullying, evaluation and monitoring were carried out through coordination and internal meetings related to the implementation of the trauma healing program, a client satisfaction index survey on a regular and ongoing basis once every 1 month for 3 to 6 months, documentation of the process implementation of the healing program (not involving the client). While the principles in monitoring and evaluating the trauma healing program are: Transparency, Accountability, Guaranteed safety, confidentiality, and approval of participants or clients of the trauma healing program, and the availability of measuring tools for changes, knowledge, and skills of the participants. Then, conduct periodic reviews after the implementation of the trauma healing program.

Trauma healing carried out by RDRM in Semarang City is a form of effort to help victims of bullying in Semarang. One of the goals of trauma healing at RDRM Semarang City is to reduce the intensity of problems related to physical, psychological, psychosocial, and environmental health in individuals, and communities. This is in line with the initial theory according to Hatta ${ }^{41}$ the implementation of trauma healing aims to help the recovery of the client's psychological condition, so that they can live a normal life again and are free from disturbances due to trauma. This program is also directed to the targets that have been identified. The goal of trauma healing in the RDRM of Semarang City is in line with the goal of trauma healing formulated by Hatta. ${ }^{42}$ The purpose of trauma healing is both to reduce the intensity of the victims' problems which involves restoring physical, psychological, psychosocial, and environmental conditions so that they live a normal life again and be free from disturbances caused by trauma.

\section{Stage Of Trauma Healing Based on Islamic Counseling and Guidance}

The stages of trauma healing at RDRM Semarang City are in line with the stage's theory of trauma healing:43

\section{a. Initial Stage}

This theory explains that in this stage the counselor builds a relationship with the client which is called a working relationship. It is a relationship that is functional, meaningful, and useful so that the client will develop trust, and release all traumas experienced. Clarify and define trauma to the client with the symptoms experienced, so that the client understands exactly what he is

\footnotetext{
${ }^{41}$ Kusmawati Hatta. Trauma dan Pemulihannya.pp.141-142

42 Ibid.

${ }^{43}$ Ibid.pp.132-133
} 
going through and the counselor helps fully. Besides, the counselor and the client agree on a time for counseling sessions.

The stages of trauma healing at RDRM in Semarang which are included in this initial stage are; first, build closeness with the client, second, get written consent from the client, third, collecting data and complete history of the client and his family, fourth, conduct a psycho test (if needed to adjust the case), fifth, found the problems experienced by the client through observation and interviews, sixth, determine the diagnosis and or comparison diagnosis, seventh determine the goals of the trauma healing program, eighth, determine the trauma healing program in the form of counseling and/or psychotherapy, ninth, make an agreement contract with the client.

\section{b. Middle Stage (Action Stage)}

This theory explains that the goal at this stage is to explore and explore the trauma, the client's concerns, and the environment in overcoming the trauma. In this stage, the counselor also maintains a memorable relationship by displaying friendliness, empathy, honesty, sincerity in helping clients. Including the action stage at the trauma healing stage at RDRM in Semarang that is the implementing stage program in the form of counseling and/or psychotherapy.

\section{c. The Final Stage or Termination Stage}

This theory explains that the stages are marked by several aspects, namely: decreased client's traumatic anxiety, changes in client behavior in a more positive, healthy, and dynamic direction, clear life goals in the future, and changes in positive attitudes towards trauma. The thing that can be done to find out changes in clients is seen from these several aspects, at the Semarang City RDRM in the final stage or the termination stage at trauma healing, namely at the stage of providing a written report on the results of the implementation of the trauma healing program and explaining the obstacles experienced and suggestions for further programs and the client's potential for recurrence.

Implementation of trauma healing to victims of bullying can reduce the intensity of problems related to physical, psychological, psychosocial, and environmental health in individuals. Trauma healing can also increase the positive potential and minimize the negative risk of bullying victims. The trauma healing counselors can assist and help bullying victims deal with their problems.

The purpose of trauma healing at RDRM Semarang City, as the author found in the field that victims felt the benefits after participating in the trauma healing program provided by RDRM Semarang. These benefits can provide positive changes to victims of bullying and they feel it is helpful to solve the problem. This is as stated by the child victim who needs help to overcome the problems they face. because the impact is very dangerous for the victim. Those victims of bullying experience depression and anger. Victims also feel sick, stay away from school, decrease in academic achievement, increase fear and anxiety, have suicidal ideation, and in the long run will experience internal difficulties which include low self-esteem, anxiety, and depression. The impact of bullying is very dire if no one assists the victim. The prevention process is an absolute thing that must be done but for victims who have experienced it, a solution is needed so that the problems they face can be resolved and the victims can get out of the problems they face.

Trauma healing at the RDRM in Semarang is an effort of the Semarang Government to help victims solving the problems faced. Trauma healing which is carried out at RDRM Semarang is very relevant to Islamic counseling guidance which is an activity to provide guidance, lessons, and guidelines to individuals in terms of how a client should be able to develop the potential of mind, psyche, faith, belief, and can tackle the problems of life properly in line with the Al-Quran and AsSunnah. 44

\footnotetext{
${ }^{44}$ Hamdani Bakran Adz-Dzaky. Konseling dan Psikoterapi Islam.pp.137
} 
Psychotherapy is given by RDRM to child victims of bullying for trauma healing using several therapies, namely play therapy, emotional catharsis, fairy tale therapy, and writing therapy. The therapy can be done individually or in groups. If it is done in a group, then the therapy is followed by the client to get the same therapy according to their needs.

Play therapy at RDRM Semarang uses structured games. The games have goals, methods, and rules that can teach certain values such as sharing and cooperation. The game is carried out in a play therapy room where various tools are available for play therapy. In the play therapy room, various educational game tools are used for therapy for them. As the initial theory free play activities can improve children's self-expression abilities. ${ }^{45}$ Structured games are games that have goals, methods, and rules that can teach certain values such as sharing and cooperation, so preparations make the implementation orderly.

Emotional catharsis was carried out at the RDRM of Semarang City by popping a plastic bag filled with water. The counselor provides several plastic bags of various colors. They choose one of the available colors. The color chosen by them is a symbol of the feelings that are being felt. Then, the victim can pop the plastic bag filled with colored water by throwing it hard at the wall. This is in line with the initial theory. ${ }^{46}$ The examples of emotional catharsis in trauma recovery are popping plastic bags loudly, and writing letters. At RDRM Semarang, emotional catharsis was carried out as a release of restrained emotions so that catharsis became a beneficial therapeutic effect for a victim. This is by the theory proposed by Wahyuningsih who stated that suppressed emotions can cause excessive emotions, therefore to release these restrained emotions is needed. ${ }^{47}$ This constructive media to release emotions is known as catharsis. At the time, Freud thought that releasing suppressed emotions could have a beneficial therapeutic effect.

Fairy tale therapy at RDRM Semarang given to victims of bullying has story values adjusted to their problems and needs so that children can look inside and recognize themselves better through the experiences given in the story. The RDRM Semarang has provided various fairy tale books that have been compiled according to the circumstances of the victims and those who give fairy tales to victims can be counselors and even parents at home with monitoring and direction from the RDRM counselor. This is in line with the initial theory which stated that fairy tale therapy has several benefits for children such as being able to look inside themselves and recognize themselves better through experiences given in stories. ${ }^{48}$ Fairy tales in the form of stories can also motivate children through the experiences given in stories, storytelling also has usefulness in fostering social relationships.

Writing therapy has cathartic power or emotional release because by writing the client can calm his mind and release tension. Writing therapy at RDRM Semarang is intended for children aged 10 years to 19 years old and even adults. Writing therapy is usually done together at the Semarang City RDRM office and can be applied at home. The counselor gives time for victims to write in the book provided. They wrote stories about the feelings related to the bullying that had happened to them. As the initial theory, Kharismawan writing has cathartic power (emotional release). ${ }^{49}$ By writing, a person will be able to calm his mind, release tension, unravel the confusion and open a new path in his life. 50

The objectives of Islamic guidance and counseling according to Adz-Dzaky include:

1. To produce a change, improvement, health, and mental and mental cleanliness.

2. To produce divine potential, so that with this potential individual can serve as caliphs properly and correctly, able to overcome various life problems, provide benefits and safety for the environment.

\footnotetext{
${ }^{45}$ Kuriake Kharismawan. Panduan Program Psikososial Paska Bencana.pp.40

${ }^{46}$ Kusmawati Hatta. Trauma dan Pemulihannya.pp.53

${ }^{47}$ Sri Wahyuningsih. Teori Katarsis dan Perubahan Sosial. (Yogyakarta: Andi Offset, 2017).pp.40.

48 Suci Paramitha. Mendongeng sebagai Metode Pemulihan Trauma pada Anak-Anak di Daerah Pasca

Bencana: Sebuah Analisis Life History Pustakawan Pendongeng. (Depok: Universitas Indonesia, 2011).pp.11

${ }^{49}$ Kuriake Kharismawan. Panduan Program Psikososial Paska Bencana.pp.11

50 Ibid.pp.42
} 
This is in line with the goals of trauma healing for children who are victims of bullying at RDRM Semarang, namely:

1. Reduce the intensity of problems involving physical, psychosocial, and environmental health in individuals, and communities.

2. Increase the positive potential and minimize the negative risk the client has.

3. Accompany and help clients to deal with their problems.

The purpose of Islamic counseling guidance, if it is associated with the implementation of trauma healing to victims at RDRM Semarang, namely: to increase the positive potential and minimize the negative risks of child victims of bullying so that they can overcome problems related to physical health, psychosocial, and the environment.

Based on the function of Islamic counseling guidance, the implementation of trauma healing for victims conducted by RDRM Semarang has implemented various functions. Here's the description: First, the function of remedial or rehabilitative is to cure psychological problems faced by child victims, restore mental health, and overcome emotional disorders. The remedial or rehabilitative function can be realized by implementing the trauma healing program in the form of counseling and/or psychotherapy.

Second, education or development functions by assisting clients in identifying and solving problems. The function of education or this development can be realized by conducting an assessment of children who are victims of bullying so that they can provide therapy according to their needs. With these therapies, the problems faced by them can be resolved.

In this case, the implementation is conducted face to face with the victims. The direct method can be further broken down into Individual methods and group methods by communicating directly to the victims. This can be done by using a personal conversation technique, in which the counselor conducts a direct dialogue face to face with the client. This method is one form that is considered very good and effective by the counselor because the client will have a clear understanding of the counselor to overcome or solving the problems he faces.

\section{E. Conclusion}

After researching the Implementation of trauma healing to victims at the RDDM Semarang, the results showed that the implementation of trauma healing to the bullying victims at the Rumah Duta Revolusi Mental in Semarang City had two forms of programs, namely counseling and psychotherapy including several therapies, namely play therapy, emotional catharsis, fairy tale therapy, and, writing therapy. Meanwhile, trauma healing is carried out through three stages, namely the initial stage, the middle stage or the work stage, and the final stage or the termination stage. Techniques, stage, and strategies show any implementation of goals and functions of Islamic counseling guidance.

The author would like to contribute his thoughts or suggestions as follows: First, for RDDM Semarang, it is better to increase socialization to schools and the public in Semarang particularly. Second, for the Central Java government, it is better to increase the socialization about the trauma healing programs of RDRM and how to handle victims. Then, RDRM Semarang should make a program to prevent bullying. This bullying prevention program, especially in Semarang, can solve problems so the cases also are reduced.

\section{References}

Adz-Dzaky, Hamdani Bakran. Konseling dan Psikoterapi Islam. Yogyakarta: Fajar Pustaka Baru, 2004.

Al Habsyi, Bakharudin. Model Bimbingan Kelompok Pola Pikir Pemecahan Masalah (PPPM) untuk Mengembangkan Pikiran Rasional Korban Bullying Siswa SMK Etnis Jawa. Jurnal Pendidikan (Teori dan Praktik) Volume 2 Nomor 2, . 2017

Amin, Samsul Munir. Bimbingan dan Konseling Islam. Jakarta: Amzah, 2010. 
Echols, John M. \& Shadiliy, Hassan. Kamus Inggris - Indonesia. (Jakarta: PT Gramedia Pustaka Utama, 2005)

Gordon, Jill. "Fostering students' personal and professional development in medicine: a new framework for PPD". Medical Education Journal 37, no.4 (2003).pp.341-349. https://doi.org/10.1046/j.1365-2923.2003.01470.x

Hasibuan, Rosya Linda, dkk. "Efektivitas Rational Emotive Behavior Therapy (REBT) untuk Meningkatkan Self Esteem pada Siswa SMP Korban Bullying". Jurnal Psikologi 11 No. 2, (2015).

Hatta, Kusmawati. Trauma dan Pemulihannya. Banda Aceh: Ar- Raniry Press, 2016.

Heriansyah, Masnurrima. Strategi Mengatasi Trauma pada Korban Bullying Melalui Konseling Eksistensial. Jurnal Ilmiah dalam Implementasi Kurikulum Bimbingan dan Konseling, 2017.

Iswarso, Nur. Mendampingi dan Menyembuhkan Anak-Anak dari Trauma Pelecehan Seksual. Yogyakarta: Penerbit Indoliterasi, 2017.

Kementerian Agama RI. Al Quran Terjemahan. Jakarta: Quranidea, 2012.

Kharismawan, Kuriake. Panduan Program Psikososial Paska Bencana. Semarang: Center For Trauma Recovery Unika Soegijapranata, 2008.

Kibtyah, Maryatul. Sistematisasi Konseling Islam. Semaarang : RaSAIL Media Group, 2015.

Mawardah, Mutia. Hubungan antara Regulasi Emosi dengan Perilaku Bullying. Yogyakarta: Universitas Islam Indonesia, 2009.

Mudjijanti, Fransisca. School Bullying dan Peran Guru dalam Mengatasinya. portal.widyamandala.ac.id, 2012.

Olweus, D. Bullying in School: Facts and Intervention. Norwegia Research Center for Health Promotion, University of Bergen. Diambil dari http://www.nigz.nl/upload/presentatiolweus.pdf pada tanggal 17 Mei 2019

Paramitha, Suci. Mendongeng sebagai Metode Pemulihan Trauma pada Anak-Anak di Daerah Pasca Bencana: Sebuah Analisis Life History Pustakawan Pendongeng. Depok: Universitas Indonesia, 2011.

Karimah, Risa. Trauma Healing Oleh Muhammadiyah Disaster Management Center (MDMC) Untuk Anak Korban Bencana (Studi Kasus Bencana Tanah Longsor di Desa Sampang, Kecamatan Karangkobar, Banjarnegara Jawa Tengah), 2015.

Kustanti, Erina ratna." Gambaran Bullying pada Pelajar di Kota Semarang".Jurnal Psikologi 14, no.1 (2015).pp.29-39. https://doi.org/10.14710/jpu.14.1.29-39.

Salsabiela, Wardha. Hubungan antara Pola Asuh Authoritative Orang Tua dengan Empati Anak pada Bystander Bullying. Yogyakarta: Universitas Gajahmada, 2010.

Sandoval, J. Handbook of Crisis Counseling, Intervention, and Prevention in The School. New Jersey. LEA Publisher, 2002.

Sugiyono. Metode Penelitian Pendidikan. Bandung: Alfabeta, 2016.

Vebriarto, dkk. Kamus Pendidikan. Jakarta: Gramedia, 1988.

Wahyuningsih, Sri. Teori Katarsis dan Perubahan Sosial. Yogyakarta: Andi Offset, 2017.

Wiyani, Novan Ardy. Save Our Children from School Bullying. Yogyakarta: Ar-Ruzz Media, 2014. 
Vol. 2 No. 1, 2020

Zakiyah, Ela Zain, Sahadi Humaedi, and Meilanny Budiarti Santoso. Faktor yang mempengaruhi remaja dalam melakukan bullying. Prosiding Penelitian dan Pengabdian kepada Masyarakat 4 (2). Bandung: UPI Bandung, 2017. 